\title{
Uptake of divalent manganese from aqueous solution using cation exchange resins
}

\author{
A.A. Swelam ${ }^{1}$, M.A.El-Nawawy ${ }^{2}$, A.M.A.Salem ${ }^{3}$ A.A. Ayman ${ }^{4}$ \\ ${ }^{1,2,3}$ Department of Chemistry, Faculty of Science, Al-Azhar University, Cairo, Egypt \\ E- Mail; abdelsamihswelam@yahoo.com
}

${ }^{4}$ Department of basic Science, Faculty of Engineering, Modern University for technology \& information, Cairo, Egypt

\section{ABSTRACT}

E-Mail; Aymaan_2010@yahoo.com

The present work deals with the removal of highly toxic manganese ion from aqueous solution using cation exchange resins namely, Amberjet $1500 \mathrm{H}$, Amberjet $1300 \mathrm{H}$ and Amberlite IRC86. The study was carried out in medium of various ionic strengths $(1.98$ to $9.98 \mathrm{mmol} / \mathrm{L})$, different resin dose $(0.25$ to $8.0 \mathrm{gm})$ and a wide solution acidity range $(0.001$ to 1.0 M), in addition to at three temperatures $(293,308$ and $318 \mathrm{~K}$ ). The aim of this study was to understand the mechanisms that govern manganese removal and find a suitable equilibrium isotherm and kinetic model for the manganese removal in a batch reactor. The experimental isotherm data were analyzed using the Langmuir, Freundlich, Temkin and DubininRadushkevich (D-R) equations. The experimental data were analyzed using four adsorption kinetic models - the pseudo first- and second-order, intraparticle diffusion and the Elovich equations - to determine the best fit equation for the adsorption of manganese ions onto the resins. The rate constants, equilibrium capacities and related correlation coefficients for each kinetic model were calculated and discussed. Also, predicted $q_{t}$ values from the kinetic equations were compared with the experimental data. Thermodynamic parameters, involving $\Delta H, \Delta S$ and $\Delta G$ were also calculated from graphical interpretation of the experimental data.

Keywords: Mn(II); Adsorption; Removal; Kinetics; Thermodynamic

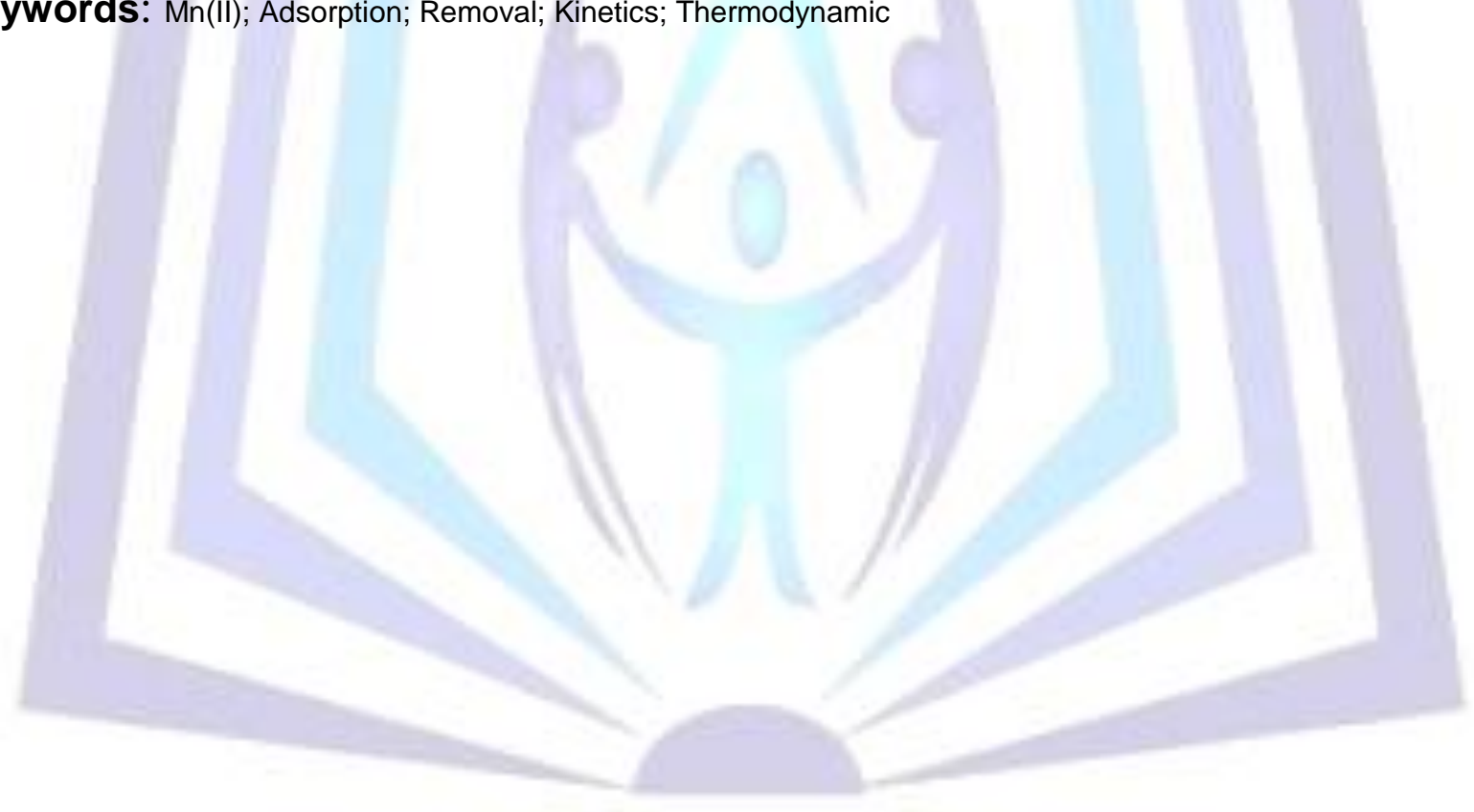

\section{Council for Innovative Research}

Peer Review Research Publishing System

Journal: Journal of Advances in Chemistry

Vol.12, No. 4

www.cirworld.com, editor@cirworld.com 


\section{INTRODUCTION}

Heavy metal contamination in water is a global problem. These metals come from various industries such as metal finishing, metallurgy, electroplating, chemical manufacturing, mining, and battery industries. Industrial wastewater containing large quantities of heavy metals causes harmful effects on the ecosystem. Removal and recovery of heavy metals from aquatic environment can be accomplished by various physical and chemical methods such as adsorption, chemical precipitation, ion exchange, membrane filtration and solvent extraction. Among all these methods, some require costly equipment and some are not efficient for complete removal of heavy metals, especially when the metal ions are present at low concentration. The adsorption process is often recommended for the removal of metal ions when they are present at low concentrations[1,2,3]. Manganese is a heavy metal, usually present in ground water as $\mathrm{Mn}(\mathrm{II})$ and is regarded as a pollutant because of its adverse effect on health. Studies show that prolonged inhalation of manganese causes neurological problems in humans. In case of rats inhalation of manganese may damage the astrocytes of their central nervous system [4].

Manganese is present in large quantities in the wastewater of many industries, and needs proper treatment before it is released. Conventional treatment for $\mathrm{Mn}(\mathrm{II})$ removal generally requires the use of strong oxidizing agents such as potassium permanganate, chlorine, hypochlorite, chlorine dioxide and ozone. Adsorption based methods are also effective because they are more economic and easy to use. The reported adsorbent materials for $\mathrm{Mn}$ (II) removal from aqueous solution include chemically treated modified plant waste [1], natural zeolite [2], clay mineral [3], fruit shell [5], Albiziaprocera legumes[6], activated Chilean zeolites [7], carbon aerogel [8], manganese oxide coated zeolite[9], hematite[10], natural and modified clay[11], activated carbon from coconut shell[12] and granular activated carbon[13].

The main objective of this study was to investigate the equilibrium and kinetic parameters of manganese onto Amberjet $1500 \mathrm{H}$, Amberjet $1300 \mathrm{H}$ and Amberlite IRC86 cation exchange resins. In addition, various parameters such as Mn(II) ion concentration, solution acidity, amount of resin, temperature were studied to optimize the conditions for effective removal of manganese ion from aqueous solution.

\section{CHEMICALS AND REAGENTS}

The following chemicals (Analytical grade) were employed: Manganese(II) chloride, hydrochloric acid. Solutions were prepared with redistilled water. All the chemicals were used as purchased, unless otherwise stated.

\section{Resin}

A strong-acid cation exchange resin Amberjet $1500 \mathrm{H}$ and Amberjet $1300 \mathrm{H}$ with sulphonic acid group $\left(-\mathrm{SO}_{3} \mathrm{H}\right)$ and Amberlite IRC86 with carboxylic group was used in this work. Finally, resin was washed with redistilled water several times until the resulting water become neutral. Finally, the resin was dried at $100-105^{\circ} \mathrm{C}$ for $24 \mathrm{~h}$.

\section{BATCH EXPERIMENTS}

Kinetics experiments were carried out in a thermostated shaker at $20 \pm 0.5^{\circ} \mathrm{C}$ and $100 \pm 10 \mathrm{rpm} .0 .5 \mathrm{~g}$ of the resin and 50 $\mathrm{ml}$ of manganese chloride aqueous solution were stirred in the shaker. Furthermore the adsorption studies were also carried out by varying time interval $(5.0-420 \mathrm{~min})$ at $5.98 \mathrm{mmol} / \mathrm{l}$ concentration of the manganese ion to optimize the time required for the removal of this metal ion from its solution. Samples were withdrawn at desired time intervals. Complexometric titration technique was used to determine the $\mathrm{Mn}$ (II) concentration in the supernatants after the adsorption onto the resin.

The amount of metal ion adsorbed per unit of adsorbent $\left(q_{e}\right)$ and removal yield $(R \%)$ were calculated by Eqs. (1) and (2), respectively:

$$
\mathrm{q}_{\mathrm{e}}=\frac{\left(\mathrm{C}_{0}-\mathrm{C}_{\mathrm{e}}\right) \mathrm{V}}{\mathrm{W} \times 1000}
$$

where $\mathrm{q}_{\mathrm{e}}$ is the equilibrium adsorption capacity $\left(\mathrm{mmol} \mathrm{g}^{-1}\right), \mathrm{C}_{\mathrm{o}}$ and $\mathrm{C}_{\mathrm{e}}$ is the metal ion concentration $\left(\mathrm{mmol} \mathrm{L}^{-1}\right)$ at initial and equilibrium state, respectively, $\mathrm{V}$ is the volume of solution $(\mathrm{mL})$ and $\mathrm{W}$ is the mass $(\mathrm{gm})$ of adsorbent.

\section{RESULTS AND DISCUSSION}

\section{Effect of initial manganese concentration}

The effect of initial manganese concentration on the efficiency of its adsorption onto the three resins was investigated in the initial concentration range of 2.06 to $9.88 \mathrm{mmol} / \mathrm{L}$ and the results are shown in Fig. 1. From this figure we can observe that, by increasing the initial manganese concentration, the percentage amount of manganese removal increased onto both Amberjet $1500 \mathrm{H}$ and Amberjet $1300 \mathrm{H}$ increase of manganese concentration upto $5.98 \mathrm{mmol} / \mathrm{l}$. with increase of manganese concentration, 8.08 and $9.98 \mathrm{mmol} / \mathrm{l}$, we can observe the percentage amount of manganese removal decreased from 74.56 to $60 \%$ and from 76.83 to $63.64 \%$ by Amberjet $1500 \mathrm{H}$ and Amberjet $1300 \mathrm{H}$, respectively. At a constant resin concentration, the decrease in the adsorption percentage is probably due to the saturation of the active binding sites on the resin surface at higher manganese concentrations. On the other hand, by increasing the initial manganese concentration the actual amount of manganese adsorbed per unit mass of the resins increased. The higher 
initial concentration of manganese provides an important driving force to overcome the mass transfer resistance for manganese transfer between the solution and the surface of the resins[14].

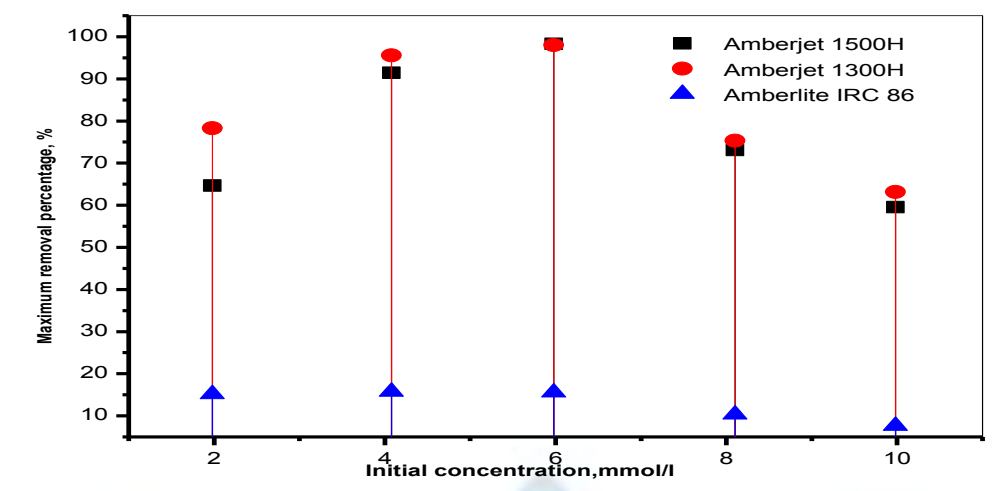

Fig. 1 Effect of initial concentration on the removal percentage of manganese from aqueous solution

It was also observed that the percentage amount of manganese removal increased by Amberlite IRC86 resin increased with a rise in the concentration of manganese up to $4.08 \mathrm{mmol} / \mathrm{l}(15.15$ and $15.69 \%)$ then, sudden decreased at higher manganese concentration (> $4.08 \mathrm{mmol} / \mathrm{l}$ ) the percentage amount of manganese removal decreased from 15.55 to $7.68 \%$. In the process, the manganese molecules primarily encounter the boundary layer effect and then diffuse from boundary layer film onto adsorbent surface and finally diffuse into the porous structure of the adsorbent, which will take relatively longer contact time. Thus, the ion-exchange resins can be efficiently used for the removal of low concentration manganese from aqueous solutions.

\section{Effect of resin dosage on adsorption}

Fig. 2 shows the removal of manganese as a function of resin dosage using Amberjet $1500 \mathrm{H}$, Amberjet $1300 \mathrm{H}$ and Amberlite IRC86 in an aqueous solution. The resin dosage varied from 0.25 to $8.0 \mathrm{~g}$ and equilibrated for $6-7 \mathrm{~h}$. It is clear that the removal percentage of manganese increases with increasing of both Amberjet $1500 \mathrm{H}$ and Amberlite IRC86 resins concentration, for the maximum removal percentage of $61.54 \%$ of manganese by Amberjet $1500 \mathrm{H}$ requires a minimum resin dose of $8 \mathrm{~g}$ and $55.52 \%$ for Amberlite IRC86, on the other hand, the removal percentage of manganese increases with increasing of Amberjet $1300 \mathrm{H}$ resin up to $2.0 \mathrm{~g}$, after $2.0 \mathrm{~g}$ resin, sudden decrease of the uptake percentage with increase of resin dose obtained. The data clearly show that the Amberjet $1500 \mathrm{H}$ has a high level of performance in terms of the removal of manganese.

The observed differences in manganese uptake by the three resins may be due to the high ion exchange capacity of $1500 \mathrm{H}, 1300 \mathrm{H}$ and low ion exchange capacity of IRC86. The experimental results revealed that the manganese removal efficiency increases up to an optimum dosage beyond which the removal efficiency does change. It may be concluded that by increasing the adsorbent dose the removal efficiency increases but adsorption density decreases [15]. The decrease in adsorption density can be attributed to the fact that some of the adsorption sites remain unsaturated during the adsorption process, whereas the number of available adsorption sites increases by an increase in adsorbent and this results in an increase in removal efficiency. As expected, the equilibrium concentration decreases with increasing adsorbent doses for a given initial manganese concentration, because for a fixed initial solute concentration, increasing the adsorbent doses provides a greater surface area or adsorption sites[16].

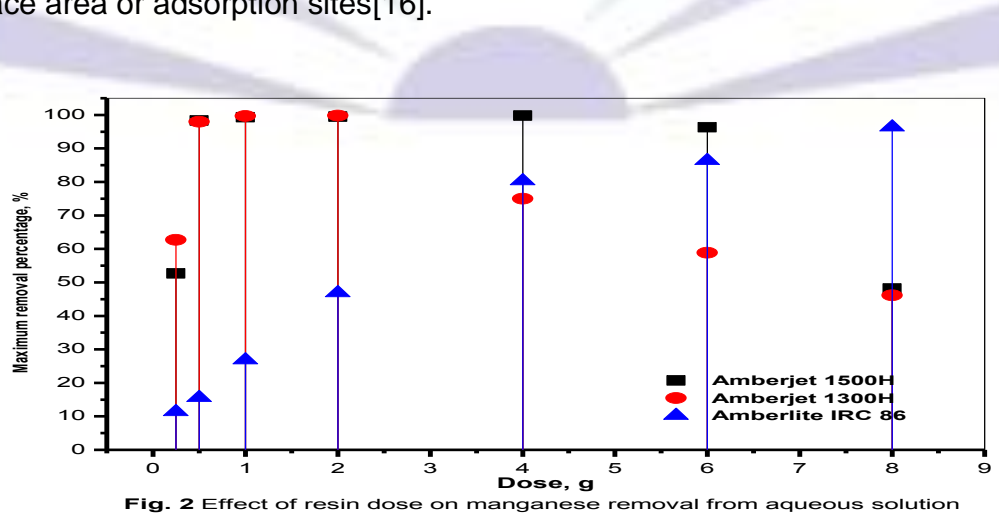

\section{The effect of solution acidity on adsorption}

The adsorption behavior of metals is significantly influenced by $\mathrm{pH}$ which affects the ionization of the surface functional groups on resins. In this study, initial $\mathrm{pH}$ values for all the experiments were controlled in the range of $0.001-1.0 \mathrm{M} \mathrm{HCl}$ to avoid the chemical precipitation of metal ions. 
Fig. 3 showed the uptake of $\mathrm{Mn}(\mathrm{II})$ at different concentrations of $\mathrm{HCl}$. An abrupt decrease of adsorption capacity was observed when $\mathrm{pH}$ changed from $0.001-1.0 \mathrm{M} \mathrm{HCl}$ then no manganese uptake after $0.01 \mathrm{M} \mathrm{HCl}$ using Amberlite IRC86 as weak cation exchange resin. Whereas, by using both Amberjet $1500 \mathrm{H}$ and Amberjet $1300 \mathrm{H}$ as strong cation exchange resins, the uptake of manganese has no significant after $1.0 \mathrm{M} \mathrm{HCl}$.

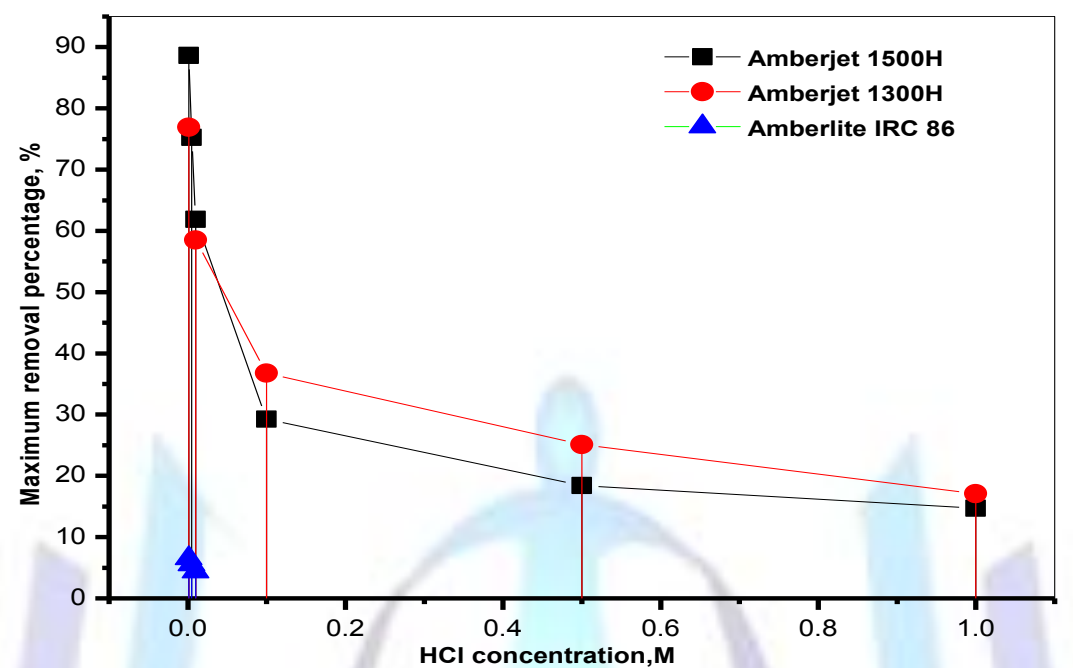

Fig. 3 Effect of $\mathrm{HCl}$ concentration on the removal of manganese from aqueous solution

The adsorption trends could be ascribed to the competition between $\mathrm{Mn}$ (II) and hydrogen ions. At low $\mathrm{pH}$, functional groups of the resin groups are present in protonated form and the active sites of the adsorbent are less available for Mn(II) due to greater repulsive forces. Hydrogen ion is the most favorable cation for weak acid resins and excessive hydrogen ions could compete with $\mathrm{Mn}(\mathrm{II})$ and further decrease the metal uptake. At intermediate $\mathrm{pH}$ values, carboxylic groups on the resin are deprotonated, hence $\mathrm{Mn}$ (II) can be adsorbed less effectively by Amberlite IRC 86 resin. However, for both Amberjet $1500 \mathrm{H}$ and Amberjet $1300 \mathrm{H}$ as strong cation exchange resins, Hydrogen ion is the lower favorable cation for sulphonate groups and excessive hydrogen ions could little compete with $\mathrm{Mn}$ (II) than carboxylic groups on the weak resin. Our results agree well with many researches[17,18, 19].

\section{The distribution ratio $(D)$}

Distribution ratio, $D$, for manganese ions was determined by the batch method at different temperature systems. The distribution ratio is defined as the ratio of metal ion concentration on the resin to that in the aqueous solution and can be used as a valuable tool to study $\mathrm{Mn}(\mathrm{II})$ ions mobility. The distribution ratio $D$ is defined by the following relationship:

$$
D=\frac{\text { Weigt (in mg)of metal ions taken up by } 1 \mathrm{~g} \text { of polymer }}{\text { Weigt (in } \mathrm{mg} \text { )of metal ions present in } 1 \mathrm{ml} \text { of solution }}
$$

Various portions of (500 mg each) the resin were taken in Erlenmeyer flasks and mixed with $50 \mathrm{ml}$ of different metal ion solutions in the aqueous medium and subsequently shaken for $24 \mathrm{~h}$ in temperatures controlled shaker at 293,308 and $318 \mathrm{~K}$ to attain the equilibrium. High values of distribution ratio (as in an aqueous-Amberjet $1500 \mathrm{H}$ and $-\mathrm{Amberjet} 1300 \mathrm{H}$ systems), indicate that the manganese has been retained by the solid phase through sorption reactions, while lower values of $D$ (as in an aqueous-Amberlite IRC86 system), indicate that a large fraction of the metal remains in solution $[2,20]$. Fig. 4 show that the distribution ratio $D$ values increase with the increase in temperatures of manganese solutions. The rapid metal sorption has significant practical importance, as this will facilitate with the small amount of resin to ensure efficiency and economy. 


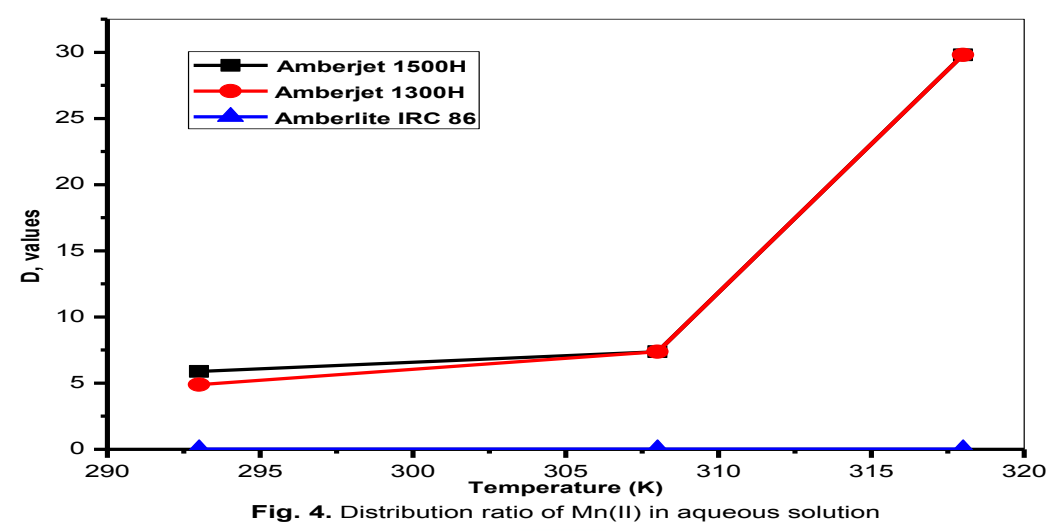

\section{Adsorption isotherms}

In order to gain a better understanding of the mechanism, four models are utilized to fit the sorption data Freundlich, Langmuir isotherm models [21,22,23,24,25,26,27,28,29].

The Langmuir isotherm is represented by the following equation:

$$
\frac{\mathrm{C}_{\mathrm{e}}}{\mathrm{q}_{\mathrm{e}}}=\frac{1}{\mathrm{~K}_{\mathrm{L}} \mathrm{Q}_{\max }}+\frac{\mathrm{C}_{\mathrm{e}}}{\mathrm{Q}_{\max }}
$$

where $C_{e}(\mathrm{mmol} / \mathrm{L})$ is the equilibrium concentration of metal ions remaining in solution, $q_{e}(\mathrm{mmol} / \mathrm{g})$ is the amount of metal ions adsorbed per weight unit of sorbent after equilibrium, $Q_{\max }(\mathrm{mmol} / \mathrm{g})$ is the maximum sorption capacity of metal ions, and $\mathrm{K}_{\mathrm{L}}(\mathrm{L} / \mathrm{mmol})$ is a constant that relates to the heat of sorption.

The Freundlich model is represented by the following equation:

$$
\log \mathrm{q}_{\mathrm{e}}=\log \mathrm{K}_{\mathrm{f}}+\frac{1}{\mathrm{n}} \log \mathrm{C}_{\mathrm{e}}
$$

where $k_{f}$ represents the sorption capacity when metal ion equilibrium concentration equals 1 , and $n$ represents the degree of dependence for sorption with equilibrium concentration.

Another equation used in the analysis of isotherms was proposed by Dubinin and Radushkevich (D-R)[27].

The D-R equation has the linear expression as follows:

$$
\ln \mathrm{q}_{\mathrm{e}}=\ln \mathrm{X}_{\mathrm{D}-\mathrm{R}}-\beta \varepsilon^{2}
$$

where $q_{e}$ is defined as above, $X_{D-R}(\mathrm{~mol} / \mathrm{g})$ is the maximum sorption capacity, $\beta$ is the activity coefficient related to mean sorption energy $\left(\mathrm{mol}^{2} / \mathrm{kJ}^{2}\right)$ and $\varepsilon$ is the Polanyi potential, which is equal to:

$$
\varepsilon=R T \ln \left(1+\frac{1}{C_{\mathrm{e}}}\right)
$$

where $\mathrm{R}$ is the ideal gas constant $\left(8.3145 \times 10^{-3} \mathrm{KJ} \mathrm{mol}^{-1} \mathrm{~K}^{-1}\right)$, and $\mathrm{T}$ is the absolute temperature $(\mathrm{K})$. The value of $\mathrm{E}_{\mathrm{D}-\mathrm{R}}$ is related to the sorption mean free energy $\left(\mathrm{kJ} \mathrm{mol}^{-1}\right)$. The relationship is expressed as:

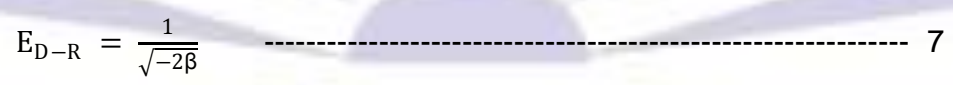

The magnitude of $E_{D-R}$ is useful to estimate the type of sorption reaction. The $E_{D-R}$ value in the range of $1-8 \mathrm{KJ}^{-1}$ indicates physical adsorption, the value between 8 and $16 \mathrm{~kJ} \mathrm{~mol}^{-1}$ signifies an ion-exchange process, its value in the range of 20-40 KJ mol ${ }^{-1}$ is indicative of chemisorption [30].

The Temkin isotherm equation assumes that the heat of adsorption of all the molecules in layer decreases linearly with coverage due to adsorbent-adsorbate interactions, and that the adsorption is characterized by a uniform distribution of the bonding energies up to some maximum binding energy. The Temkin isotherm has been used in the following form:

$$
\mathrm{q}_{\mathrm{e}}=\left(\frac{\mathrm{RT}}{\mathrm{b}_{\mathrm{T}}}\right) \ln \mathrm{A}_{\mathrm{T}}+\left(\frac{\mathrm{RT}}{\mathrm{b}_{\mathrm{T}}}\right) \ln \mathrm{C}_{\mathrm{e}}
$$

Or

$$
\mathrm{q}_{\mathrm{e}}=\mathrm{B}_{\mathrm{T}} \ln \mathrm{A}_{\mathrm{T}}+\mathrm{B}_{\mathrm{T}} \ln \mathrm{C}_{\mathrm{e}}
$$

where $R$ is gas constant $\left(8.314 \mathrm{~J} \mathrm{~mol}^{-1} \mathrm{~K}^{-1}\right), T$ is temperature $(K), A_{T}$ is the equilibrium binding constant $\left(L g^{-1}\right)$ corresponding to the maximum binding energy, and constant $\mathrm{B}_{\mathrm{T}}=\left(\mathrm{RT} / \mathrm{b}_{\mathrm{T}}\right)$ is related to the heat of adsorption. A plot of qe versus $\ln C_{e}$ (Fig. not shown) is used to calculate the Temkin isotherm constants $A_{T}$ and $B_{T}[31,32]$. 
The fitting results of $\mathrm{Mn}$ (II) adsorption on the resins are listed in Table 1. According to the values of correlation coefficients, the Langmuir model are more suitable than the Freundlich model to describe the adsorption process onto both Amberjet $1500 \mathrm{H}$ and Amberjet $1300 \mathrm{H}$. The adsorption isotherm of $\mathrm{Mn}(\mathrm{II})$ on the two resins followed the Langmuir model. It was notable that the temperature rise from 293 to $318 \mathrm{~K}$ resulted in a corresponding increase in the adsorption capacity of $\mathrm{Mn}(\mathrm{II})$, which indicated that uptake of $\mathrm{Mn}$ (II) onto the two resins was an endothermic process. Whereas adsorption isotherm of $\mathrm{Mn}$ (II) onto Amberlite IRC 86 behave opposite trends, since the values of correlation coefficients of the Freundlich model are more suitable than the Langmuir model to describe the adsorption process. The adsorption isotherm of $\mathrm{Mn}(\mathrm{II})$ onto this resin followed the Freundlich model.

For the Langmuir isotherm model, a dimensionless constant $\left(R_{\mathrm{L}}\right)$, commonly known as separation factor or equilibrium parameter can be used to describe the favorability of adsorption on the polymer surface by:

$$
\mathrm{R}_{\mathrm{L}}=\frac{1}{\left(1+\mathrm{K}_{\mathrm{L}} \mathrm{C}_{0}\right)}
$$

where $\mathrm{C}_{0}$ is the initial $\mathrm{Mn}(\mathrm{II})$ concentration and $\mathrm{K}_{\mathrm{L}}$ is the Langmuir equilibrium constant. The more favorable adsorption is reflected by lower $R_{L}$ values; the adsorption could be either unfavorable $\left(R_{L}>1\right)$, linear $\left(R_{L}=1\right)$, favorable $\left(0<R_{L}<1\right)$ or irreversible $\left(R_{L}=0\right)$. The $R_{L}$ values for the adsorption of manganese ion are given in Table 1 , which reveals that the values fall in the preferred region (i.e., $0<R_{L}<1$ ) for both Amberjet $1500 \mathrm{H}$ and Amberjet $1300 \mathrm{H}$. Whereas, the $R_{L}$ values for the adsorption of manganese ion onto Amberlite IRC86 show an opposite trend, since $R_{L}$ value $>1$. The lower value of $\mathrm{R}_{\mathrm{L}}$ for the manganese adsorption onto both Amberjet $1500 \mathrm{H}$ and Amberjet $1300 \mathrm{H}$ point toward irreversible nature of the adsorption process.

Table.1- Adsorption isotherm parameters of $\mathrm{Mn}(\mathrm{II})$ on different ion exchange resins in aqueous solution.

\begin{tabular}{|c|c|c|c|c|}
\hline \multirow{2}{*}{\multicolumn{2}{|c|}{ Isotherm parameters }} & \multicolumn{3}{|c|}{ Resins } \\
\hline & & Amberjet $1500 \mathrm{H}$ & Amberjet $1300 \mathrm{H}$ & Amberlite IRC86 \\
\hline \multirow{4}{*}{ 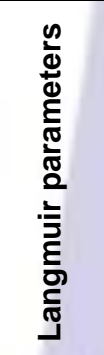 } & $Q_{\max }(\mathrm{mmol} / \mathrm{g})$ & 0.5865 & 0.5845 & 0.0153 \\
\hline & $\begin{array}{c}\mathrm{K}_{\mathrm{L}} \\
(\mathrm{L} / \mathrm{mmol})\end{array}$ & 2854.14 & 2008.24 & 0.2369 \\
\hline & $\mathbf{R}_{\mathbf{L}}$ & $5.85 \times 10^{-5}$ & $8.33 \times 10^{-5}$ & 2.40 \\
\hline & $\mathbf{R}^{2}$ & 0.9982 & 0.9912 & 0.9989 \\
\hline \multirow{3}{*}{ 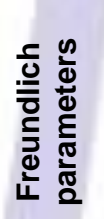 } & $\mathbf{n}$ & 124.84 & 112.49 & 0.1902 \\
\hline & $\mathrm{K}_{\mathrm{F}}$ & 0.5777 & 0.5759 & 463.7 \\
\hline & $\mathbf{R}^{2}$ & 0.9540 & 0.7769 & 0.9996 \\
\hline \multirow{3}{*}{ 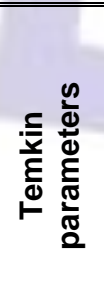 } & $\mathbf{A}_{T}$ & $1.22 \times 10^{-53}$ & $2.95 \times 10^{-48}$ & $16.46 \times 10^{2}$ \\
\hline & $\begin{array}{c}\mathrm{B}_{\mathrm{T}} \\
(\mathrm{J} / \mathrm{mol})\end{array}$ & 0.0047 & 0.0053 & 0.5024 \\
\hline & $\mathrm{R}^{2}$ & 0.9747 & 0.9278 & 1.0000 \\
\hline \multirow{4}{*}{ 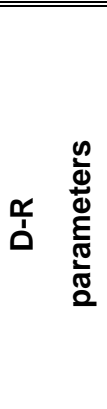 } & $\begin{array}{c}\beta \\
\left(\mathrm{mol}^{2} \mathrm{~kJ}^{-2}\right)\end{array}$ & $1.74 \times 10^{-10}$ & $1.99 \times 10^{-10}$ & $2.49 \times 10^{-7}$ \\
\hline & $\begin{array}{c}X_{D-R} \\
(\mathrm{mmol} / \mathrm{g})\end{array}$ & 0.5849 & 0.5836 & 0.0716 \\
\hline & $\begin{array}{c}E_{D-R} \\
(\mathrm{~kJ} / \mathrm{mol})\end{array}$ & 53.547 & 50.153 & 1.416 \\
\hline & $\overline{R^{2}}$ & 0.9737 & 0.8940 & 0.9327 \\
\hline
\end{tabular}


The $\mathrm{E}$ values of the Amberjet $1500 \mathrm{H}(53.547 \mathrm{~kJ} / \mathrm{mol})$ and Amberjet $1300 \mathrm{H}(50.153 \mathrm{~kJ} / \mathrm{mol})$ obtained were $>8 \mathrm{~kJ} / \mathrm{mol}$, which were in the energy range of chemisorption reaction. An opposite trend was noted for adsorption of manganese onto Amberlite IRC86, where The E value was $<8 \mathrm{~kJ} / \mathrm{mol}(1.416 \mathrm{~kJ} / \mathrm{mol})$ which was in the energy range of physisorption reaction[33,34]. The sorption capacities $X_{D-R}$ derived from the $\mathrm{D}-\mathrm{R}$ model using Amberjet $1500 \mathrm{H}, \mathrm{Amberjet} 1300 \mathrm{H}$ and Amberlite IRC86 were higher than those derived from the Langmuir model. This could be attributed to the different assumptions adopted in the formulation of the isotherms. The differences have also been reported in other work[35,36,37].

\section{Adsorption kinetics}

Kinetic studies were carried out using different models, namely, pseudo-first order, pseudo-second order, Elovich and Fickian diffusion's intraparticle model to analyse the experimental data[25,34,38,39,40,41,42,43,44,45].

The uptake-time curves (Fig. 5) showed that the maximum uptake followed the order of Amberjet $1500 \mathrm{H}>\mathrm{Amberjet}$ $1300 \mathrm{H}>$ Amberlite IRC86 at all-time intervals under the initial concentration of $5.98 \mathrm{mmol} / \mathrm{l}$ and at $293 \mathrm{~K}$. The kinetic curves revealed that the adsorption onto the three resins was initially rapid within the first 30 min, reached equilibrium after approximately 360-420 min and remained constant until the end of the experiment. In comparison, the adsorption rate onto Amberlite IRC86 was slower than that of both Amberjet $1500 \mathrm{H}$ and Amberjet $1300 \mathrm{H}$, demonstrated the slowest kinetic profile and the lowest adsorption capacity of $\mathrm{Mn}(\mathrm{II})$, reaching the equilibrium after approximately $360 \mathrm{~min}$. The rapid initial uptake indicates that the adsorption process is favourable, whereas the slower rate of uptake to reach the equilibrium is due to the diminished availability of free adsorption sites and uptake in the narrow, hindered pore regions[46].

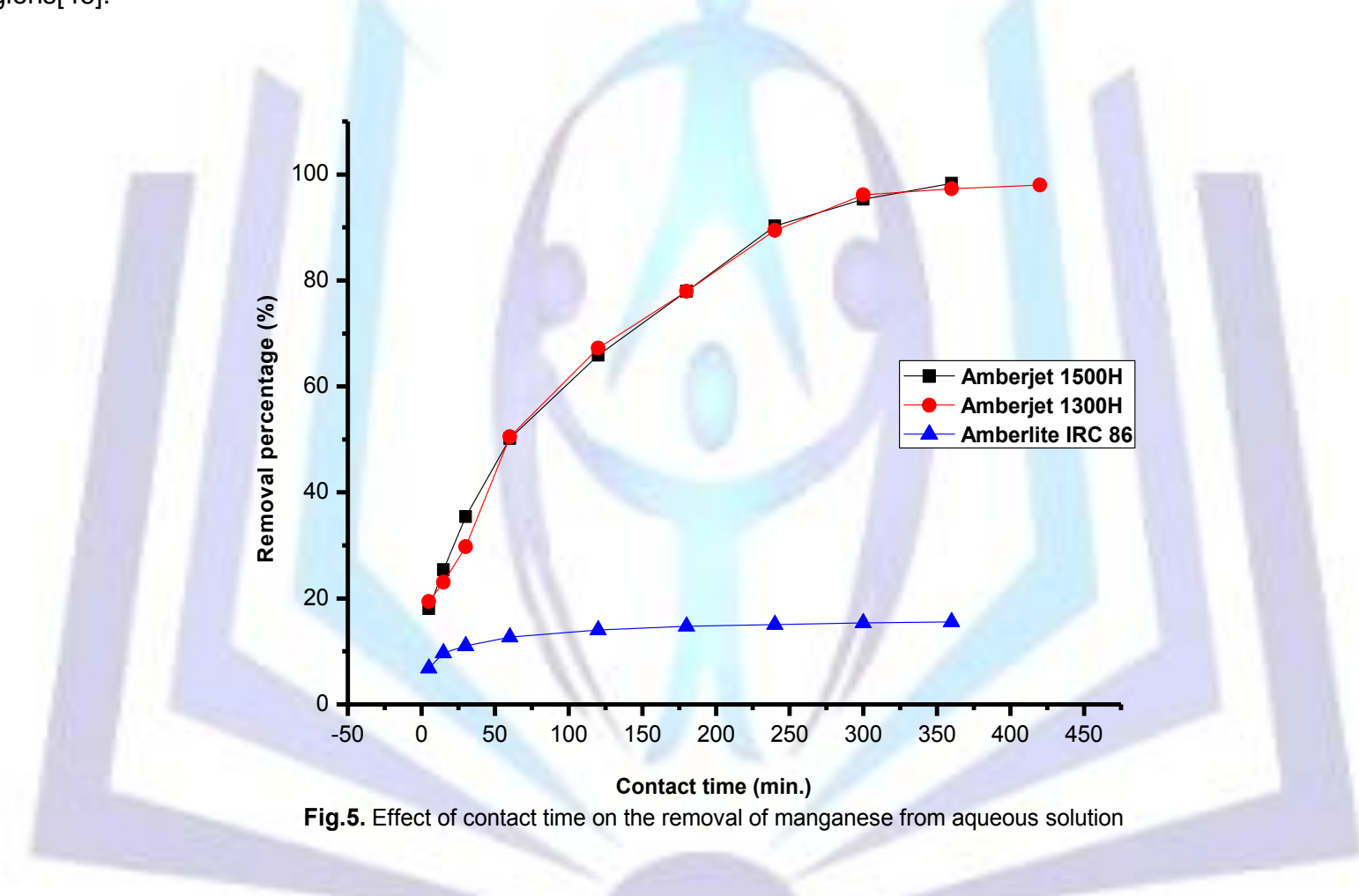

To further analyze the adsorption kinetics, four models were applied to describe the adsorption kinetics. Each model is expressed as follows.

The pseudo-first-order kinetic model is given as:

$$
\log \left(\mathrm{q}_{\mathrm{e}}-\mathrm{q}_{\mathrm{t}}\right)=\log \mathrm{q}_{\mathrm{e}, 1}-\mathrm{k}_{1} \mathrm{t}
$$

The pseudo-second-order equation is expressed as:

$$
\begin{aligned}
& \frac{\mathrm{t}}{\mathrm{q}_{\mathrm{t}}}=\frac{1}{\mathrm{k}_{2} \mathrm{q}_{\mathrm{e}, 2}^{2}}+\frac{\mathrm{t}}{\mathrm{q}_{\mathrm{e}, 2}} \quad \text { - } \\
& \mathrm{h}=\mathrm{k}_{2} \mathrm{q}_{\mathrm{e}, 2}^{2}
\end{aligned}
$$

The Elovich equation

The adsorption data may also be analyzed using the Elovich equation [45], which expressed as follows:

$$
\frac{d q_{t}}{d t}=\alpha \exp \left(-\beta q_{t}\right)
$$


To simplify the Elovich equation, Chien and Clayton [44] assumed $\alpha \beta \gg 1$ and by applying the boundary conditions $q_{t}=0$ at $t=0$ and $q_{t}=q_{t}$ at $t=t$. Eq. (14) becomes:

$$
\mathrm{q}_{\mathrm{t}}=\frac{1}{\beta} \ln (\alpha \beta)+\frac{1}{\beta} \ln t
$$

where $\alpha$ is the initial sorption rate constant $(\mathrm{mmol} / \mathrm{g} \mathrm{min})$, and the parameter $\beta$ is related to the extent of surface coverage and activation energy for chemisorption $(\mathrm{g} / \mathrm{mmol})[47]$.

Fickian diffusion law is expressed as:

$$
q_{t}=k_{\mathrm{id}} t^{0.5}+C
$$

where $\mathrm{q}_{\mathrm{t}}(\mathrm{mmol} / \mathrm{g})$ is the adsorption capacity at time $\mathrm{t}, \mathrm{q}_{\mathrm{e}}(\mathrm{mmol} / \mathrm{g})$ is the adsorption capacity at equilibrium, $\mathrm{h}(\mathrm{mmol} / \mathrm{g} \mathrm{min})$ is the initial adsorption rate constant of pseudo-second-order. $k_{1}\left(\mathrm{~min}^{-1}\right)$ and $\mathrm{k}_{2}(\mathrm{~g} / \mathrm{mmol} \mathrm{min})$ are the adsorption rate constants of pseudo-first-order, and pseudo-second-order isotherms. Constant $\mathrm{k}_{\mathrm{id}}\left(\mathrm{mmol} /\left(\mathrm{g} \mathrm{min}^{0.5}\right)\right.$ is the intra-particle diffusion rate, and $\mathrm{C}$ is the intercept of the plots (Fig. not shown). The kinetic parameters for the adsorption of Mn(II) on different adsorbents are given in Tables $2 \mathrm{a}$ and $2 \mathrm{~b}$. Different results were obtained from the kinetic models for the three resins, indicating the different adsorption kinetics of the three resins. The pseudo-first-order equation was determined to be the best model for $\mathrm{Mn}(\mathrm{II})$ adsorption onto both Amberjet $1500 \mathrm{H}$ and Amberjet $1300 \mathrm{H}$, with the highest correlation coefficients $\left(R^{2}>0.98\right)$ among the four equations (Fig. not shown).

From the results also we can observe the pseudo-second-order equation for Amberlite IRC86 was determined to be the best model for $\mathrm{Mn}(\mathrm{II})$ adsorption, with the highest correlation coefficients $\left(R^{2}>0.98\right)$ among the four equations. Therefore, it was indicated that the adsorption rate of $\mathrm{Mn}(\mathrm{II})$ depended on the manganese solution temperature at the external surface of the adsorbent. When the temperature was increased, the initial adsorption rate $\mathrm{h}(\mathrm{mmol} /(\mathrm{g} \mathrm{min}))$ of Amberjet $1500 \mathrm{H}$, Amberjet $1300 \mathrm{H}$ and Amberlite IRC86 also increased from 0.0095 to $0.0218 \mathrm{mmol} /(\mathrm{g} \mathrm{min}), 0.0106$ to 0.0298 $\mathrm{mmol} /(\mathrm{g} \mathrm{min})$ and 0.0078 to $0.0162 \mathrm{mmol} /(\mathrm{g} \mathrm{min})$, respectively. The value $\mathrm{h}$ for Amberjet $1500 \mathrm{H}$ was the highest than the two resins, suggesting that Amberjet $1500 \mathrm{H}$ possesses the fastest kinetics among three investigated resins.

A linear relationship was obtained between $q_{t}$ and $(\operatorname{In} t)$ over the whole temperatures of $\mathrm{Mn}$ (II) (figures are not shown). The correlation coefficients between 0.9463 and $0.9771,0.9379$ and 0.9871 and, 0.9887 and 0.9467 for Amberjet $1500 \mathrm{H}$, Amberjet $1300 \mathrm{H}$ and Amberlite IRC86 resins, respectively. Additionally, Table $2 \mathrm{~b}$ lists the kinetic constants obtained from the Elovich equation. The relatively high values of the correlation coefficients in all the points suggest that, the sorption of $\mathrm{Mn}$ (II) onto the three resins is may be appropriately represented by an Elovich kinetic model.

\begin{tabular}{|c|c|c|c|c|c|c|c|c|}
\hline \multirow{2}{*}{ 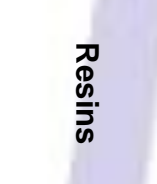 } & \multirow{2}{*}{$\begin{array}{l}-1 \\
\frac{1}{3} \\
\frac{0}{0} \\
\frac{1}{\pi}\end{array}$} & \multicolumn{3}{|c|}{ Pseudo first-order model } & \multicolumn{4}{|c|}{ Pseudo second-order model } \\
\hline & & $\begin{array}{c}q_{e, 1, \mathrm{cal}} \\
(\mathrm{mmol} / \mathrm{g})\end{array}$ & $\begin{array}{c}\mathrm{K}_{1} \\
\left(\mathrm{~min}^{-1}\right)\end{array}$ & $\mathbf{R}^{2}$ & $\begin{array}{c}q_{e, 2, \mathrm{cal}} \\
(\mathrm{mmol} / \mathrm{g})\end{array}$ & $\begin{array}{c}\mathrm{K}_{2} \\
(\mathrm{~g} / \mathrm{mmol} \mathrm{min})\end{array}$ & $\mathbf{R}^{2}$ & $\stackrel{\mathrm{h}}{\mathrm{mmol} /(\mathrm{g} \mathrm{min})}$ \\
\hline \multirow{3}{*}{$\begin{array}{c}\text { Amberjet } \\
1500 \mathrm{H}\end{array}$} & 293 & 0.5552 & 0.0104 & 0.9852 & 0.8166 & 0.0142 & 0.9099 & 0.0095 \\
\hline & 308 & 0.4922 & 0.0113 & 0.9957 & 0.6585 & 0.0353 & 0.9903 & 0.0153 \\
\hline & 318 & 0.4859 & 0.0162 & 0.9997 & 0.6655 & 0.0492 & 0.9945 & 0.0218 \\
\hline \multirow{3}{*}{$\begin{array}{c}\text { Amberjet } \\
1300 \mathrm{H}\end{array}$} & 293 & 0.6594 & 0.0128 & 0.9988 & 0.6751 & 0.0232 & 0.9844 & 0.0106 \\
\hline & 308 & 0.5058 & 0.0126 & 0.9954 & 0.6486 & 0.0403 & 0.9957 & 0.0169 \\
\hline & 318 & 0.4909 & 0.0176 & 0.9717 & 0.6314 & 0.0747 & 0.9994 & 0.0298 \\
\hline \multirow{3}{*}{$\begin{array}{l}\text { Amberlite } \\
\text { IRC86 }\end{array}$} & 293 & 0.0426 & 0.0121 & 0.9822 & 0.0953 & 0.8588 & 0.9993 & 0.0078 \\
\hline & 308 & 0.0414 & 0.0176 & 0.9787 & 0.0980 & 1.1493 & 0.9998 & 0.0110 \\
\hline & 318 & 0.0371 & 0.0214 & 0.9476 & 0.1006 & 1.6060 & 0.9991 & 0.0162 \\
\hline
\end{tabular}

Table.2a-Kinetic parameters of Mn (II) on different ion exchange resins in aqueous solution.

For Fickian diffusion law, all the correlation coefficients were relatively low and the intercept of plots revealed obvious boundary layer effect (Table $2 \mathrm{~b}$ ). Larger intercept means greater contribution of surface adsorption as the rate-controlling step. In addition, it was essential for the plots of $q_{t}$ versus $t^{0.5}$ to go through the origin if the intra-particle diffusion was the 
sole rate-limiting step. However, all the linear portions did not pass through the origin (all intercepts were in the range of 0.0502-0.1920), indicating that intra-particle diffusion maybe not only the rate-controlling factor[48,49].

Amberjet $1500 \mathrm{H}$ exhibited the fastest kinetic property for manganese removal among the three studied resins. Compared with Amberjet $1300 \mathrm{H}$, the kinetic superiority of Amberjet $1500 \mathrm{H}$ was ascribed to its higher exchange capacity and smaller particle size. On the other hand, Amberjet $1500 \mathrm{H}$ and Amberjet $1300 \mathrm{H}$ had the same matrix structure, functional groups and exchange capacity. Compared with the Amberlite IRC86 also which had different matrix structure, functional groups and exchange capacity.

This was further evidence indicating that the active sites of the three resins are mainly distributed on the external surface. The adsorption rate of Amberjet $1500 \mathrm{H}$ was faster than Amberjet $1300 \mathrm{H}$ because of its higher external surface area. Therefore, the external surface of resins was the key factor in rate-controlling[50].

Table.2b- Kinetic parameters of Mn(II) on different ion exchange resins in aqueous solution.

\begin{tabular}{|c|c|c|c|c|c|c|c|}
\hline \multirow{2}{*}{$\begin{array}{l}\underset{\mathbb{D}}{\mathbb{S}} \\
\underset{\sim}{\bar{S}}\end{array}$} & \multirow{2}{*}{$\begin{array}{l}-1 \\
\frac{D}{3} \\
\frac{7}{0} \\
\pi\end{array}$} & \multicolumn{3}{|c|}{ Intraparticle diffusion model } & \multicolumn{3}{|c|}{ Elovich model } \\
\hline & & $\begin{array}{c}\mathrm{K}_{\text {int }} \\
\mathrm{mmole} / \mathrm{g} \mathrm{min}^{-0.5}\end{array}$ & $\begin{array}{c}\text { C } \\
(\mathrm{mmol} / \mathrm{g})\end{array}$ & $\mathbf{R}^{2}$ & $\alpha$ & $\beta$ & $\mathbf{R}^{2}$ \\
\hline \multirow{3}{*}{$\begin{array}{c}\text { Amberjet } \\
1500 \mathrm{H}\end{array}$} & 293 & 0.0301 & 0.0502 & 0.9891 & 0.0339 & 8.2210 & 0.9463 \\
\hline & 308 & 0.0322 & 0.0694 & 0.9731 & 0.0426 & 8.0985 & 0.9672 \\
\hline & 318 & 0.0354 & 0.0944 & 0.9525 & 0.0576 & 7.8821 & 0.9771 \\
\hline \multirow{3}{*}{$\begin{array}{c}\text { Amberjet } \\
1300 \mathrm{H}\end{array}$} & 293 & 0.0288 & 0.0546 & 0.9668 & 0.0319 & 8.0782 & 0.9379 \\
\hline & 308 & 0.0286 & 0.1037 & 0.9481 & 0.0480 & 8.3570 & 0.9827 \\
\hline & 318 & 0.0247 & 0.1920 & 0.8576 & 0.0962 & 9.2481 & 0.9871 \\
\hline \multirow{3}{*}{$\begin{array}{l}\text { Amberlite } \\
\text { IRC86 }\end{array}$} & 293 & 0.0030 & 0.0453 & 0.8646 & 0.0890 & 82.5764 & 0.9887 \\
\hline & 308 & 0.0036 & 0.0462 & 0.7609 & 0.0678 & 71.0227 & 0.9467 \\
\hline & 318 & 0.0033 & 0.0583 & 0.8815 & 0.5261 & 91.3242 & 0.9862 \\
\hline
\end{tabular}

\section{Adsorption thermodynamics}

The effect of temperature on the adsorption of $\mathrm{Mn}(\mathrm{II})$ from aqueous solution onto the three ion-exchange resins was performed to evaluate the influence of metal ion adsorption capacity. The removal percentage of $\mathrm{Mn}$ (II) onto the Amberjet $1500 \mathrm{H}$, Amberjet $1300 \mathrm{H}$ and Amberlite IRC 86 ion-exchange resins (Fig. not shown) was raised from 98.33 to $99.67 \%$, 97.99 to $99.67 \%$ and 15.55 to $16.39 \%$ for the three resins, respectively, with increase in temperature from 293 to $318 \mathrm{~K}$. This may be due to the formation of new active sites in the ion-exchange resins to increase in temperature. The adsorption amount also augmented with an increase of temperature. For the three resins, the amount of $\mathrm{Mn}$ (II) adsorbed order generally follows the sequence; Amberjet $1500 \mathrm{H}>$ Amberjet $1300 \mathrm{H}>$ Amberlite IRC86 at all temperatures under the initial concentration of $5.98 \mathrm{mmol} / \mathrm{l}, 50 \mathrm{ml}$ manganese solution and $0.5 \mathrm{~g}$ of each resin. Increase of adsorption capacities of manganese on three resins as the temperature increased (Fig. 6), indicating also an endothermic process and a possible type of chemical adsorption mechanism occur.

The thermodynamic parameters provide in-depth information on inherent energetic changes that are associated with adsorption, including free energy change $\left(\Delta G^{\circ}\right)$, enthalpy change $\left(\Delta H^{\circ}\right)$ and entropy change $\left(\Delta S^{\circ}\right)$, which can be estimated by the following equations, $[17,51,52]$.

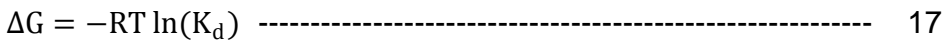

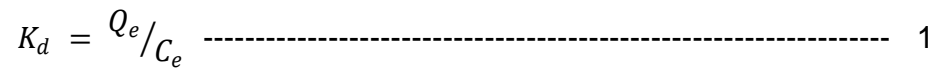

$$
\begin{aligned}
& \ln \mathrm{K}_{\mathrm{d}}=\frac{\Delta \mathrm{S}}{\mathrm{R}}-\frac{\Delta \mathrm{H}}{\mathrm{RT}}---19
\end{aligned}
$$

where $\mathrm{K}_{\mathrm{d}}$ is the equilibrium constant, $\Delta \mathrm{H}^{\circ}(\mathrm{kJ} / \mathrm{mol})$ is the change in enthalpy, $\Delta \mathrm{S}^{\circ}(\mathrm{J} /(\mathrm{mol} . \mathrm{K}))$ is the change in entropy, $\Delta \mathrm{G}^{\circ}$ $(\mathrm{kJ} / \mathrm{mol})$ is the Gibbs free energy, $T(K)$ is the absolute temperature and $R(8.314 \mathrm{~J} /(\mathrm{mol} \mathrm{K}))$ is the gas constant. 
The calculated thermodynamic parameters are presented in Table 3. All of the $\Delta \mathrm{H}^{\circ}$ values were positive, demonstrating an endothermic process. The negative values of $\Delta \mathrm{G}^{\circ}$ at aqueous-manganese- Amberjet $1500 \mathrm{H}$ and Amberjet $1300 \mathrm{H}$ systems accompanied by the positive $\Delta S^{\circ}$ suggested that the sorption reactions are spontaneous with a high affinity for $\mathrm{Mn}(\mathrm{II})$. This may be due to at high temperature, $\mathrm{Mn}$ (II) was readily desolvated, and thereby its uptake by the resin was favored. However, adsorption process onto Amberlite IRC86, $\Delta \mathrm{G}^{\circ}$ became positive values at all temperatures, which indicated presence of energy barrier.

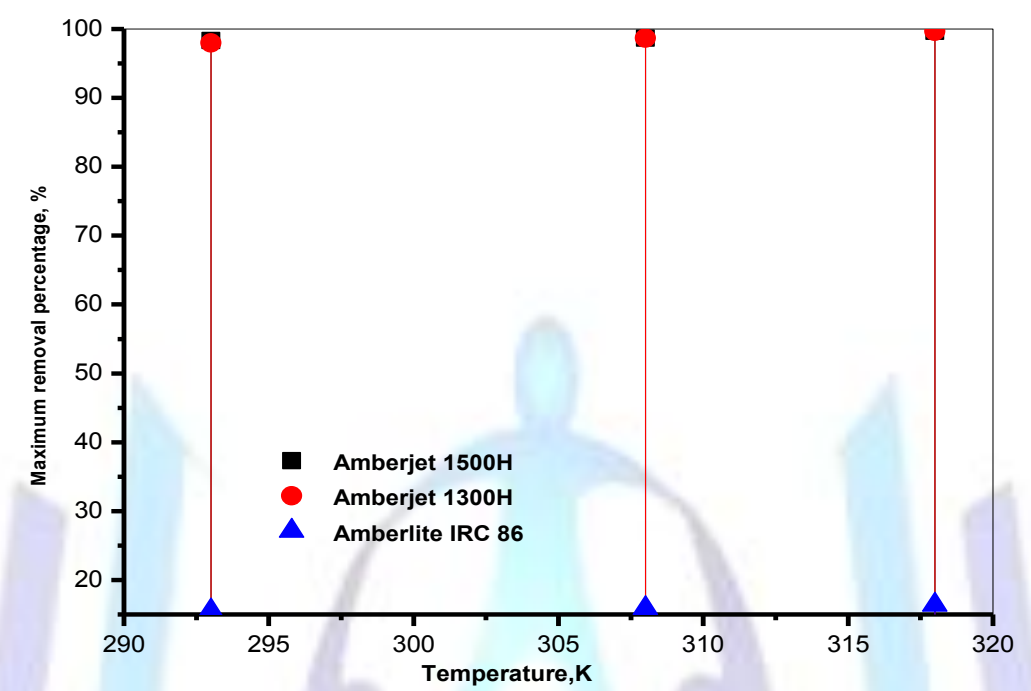

Fig. 6. Effect of temperature on the removal of manganese from aqueous solution

The positive enthalpy change $\left(\Delta \mathrm{H}^{0}\right)$ values for the metal ions adsorption reaction (Table 3$)$ indicate the endothermic nature of the present reaction. $\Delta \mathrm{H}^{\circ}$ values obtained from adsorption of $\mathrm{Mn}$ (II) onto Amberlite IRC86 cation exchange resin are lower than that onto Amberjet $1500 \mathrm{H}$ and Amberjet $1300 \mathrm{H}$. This result for $\mathrm{Mn}$ (II) gives clear evidence that the interactions between $\mathrm{Mn}$ (II) ion and the carboxylic groups of the Amberlite IRC86 resin may be weaker than that of sulphonic groups of both Amberjet $1500 \mathrm{H}$ and Amberjet $1300 \mathrm{H}$ resins. The high value of $\Delta \mathrm{H}^{0}\left(>40 \mathrm{~kJ} \mathrm{~mol}^{-1}\right.$ ) for $\mathrm{Mn}$ (II) onto both Amberjet $1500 \mathrm{H}$ and Amberlite IRC86 resins indicated that adsorption process occurs mainly through a chemical means. Whereas, The low value of $\Delta \mathrm{H}^{0}\left(<40 \mathrm{~kJ} \mathrm{~mol}^{-1}\right)$ for $\mathrm{Mn}$ (II) onto Amberlite IRC86 resin indicated that adsorption process occurs mainly through physical means $O n$ the other hand, the positive values of $E_{a}$ and $\Delta H^{\circ}$ indicate the presence of an energy barrier in the adsorption process[53,54,55,56].

The positive values for these parameters are quite common because the activated complex in the transition state is in an excited form. However, the negative values of $\Delta \mathrm{G}^{0}$ increases with increasing temperature indicate the feasibility and spontaneity of the metal ion adsorption process on the resin. However, adsorption process onto Amberlite IRC86, $\Delta G^{\circ}$ became positive values at all temperatures, which indicated presence of energy barrier. The positive entropy change $\left(\Delta S^{0}\right)$ for this reaction (Table 3 ) has also indicated the increase in number of species at the solid-liquid interface and, hence the randomness in the interface which is presumably due to the release of aqua molecules when the aquated metal ion is adsorbed on the surface of the adsorbent and significant changes occur in the internal structure of the adsorbent through the adsorption of the metal ions onto the resinand vice versa[57] .

A linear relationship can be found out in (Figs. not shown) with a regression coefficient $R^{2}$ in Table $3 E_{a}$ values for Mn(II) are observed to be $46.121,52.106$ and $0.297 \mathrm{KJ} / \mathrm{Mol}$ for Amberjet $1500 \mathrm{H}$, Amberjet $1300 \mathrm{H}$ and Amberlite IRC86 resins, respectively.

These results, as tabulated in Table 3 are indicating that the adsorption has a slightly higher potential barrier for both Amberjet $1500 \mathrm{H}$ and Amberjet $1300 \mathrm{H}$ resin systems and prove that the sorption process is chemisorption nature. Whereas, Amberlite IRC86 has a lower potential barrier compared to the two resin systems and demonstrate that the sorption process is physisorption nature.

In order to further support the assertion that the adsorption is the predominant mechanism, the values of the activation energy $\left(E_{a}\right)$ and sticking probability $\left(S^{*}\right)$ were estimated from the experimental data. They were calculated using a modified Arrhenius type equation related to surface coverage as expressed in equations:

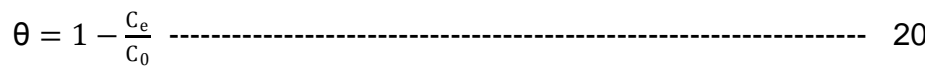

$$
\begin{aligned}
& S^{*}=(1-\theta) \exp \left(-\frac{E_{a}}{R T}\right)
\end{aligned}
$$


The sticking probability, $\mathrm{S}^{*}$, is a function of the adsorbate/adsorbent system under consideration and is dependent on the temperature of the system. The parameter $S^{*}$ indicates the measure of the potential of an adsorbate to remain on the adsorbent indefinitely. It can be expressed as in Table 3.

Table 3- Thermodynamic parameters of $\mathrm{Mn}$ (II) on different ion exchange resins in aqueous solution

\begin{tabular}{|c|c|c|c|}
\hline \multirow[b]{2}{*}{ Thermodynamic parameters } & \multicolumn{3}{|c|}{ Resins } \\
\hline & $\begin{array}{c}\text { Amberjet } \\
1500 \mathrm{H}\end{array}$ & $\begin{array}{c}\text { Amberjet } \\
1300 \mathrm{H}\end{array}$ & $\begin{array}{c}\text { Amberlite } \\
\text { IRC86 }\end{array}$ \\
\hline$\Delta \mathbf{S}(\mathrm{J} / \mathrm{mol} . \mathbf{K})$ & 171.874 & 191.286 & -26.869 \\
\hline$\Delta \mathrm{H}(\mathrm{KJ} / \mathrm{mol})$. & 46.515 & 52.613 & 1.866 \\
\hline $\mathbf{R}^{2}$ & 0.486 & 0.635 & 0.881 \\
\hline Temp., K & & $\Delta \mathbf{G}$ & \\
\hline 293 & -4.315 & -3.863 & 9.730 \\
\hline 308 & -5.116 & -5.116 & 10.164 \\
\hline 318 & -8.974 & -8.974 & 10.396 \\
\hline & . & & 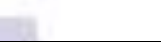 \\
\hline $\mathbf{S}^{*}$ & $1.22 \times 10^{-10}$ & $1.23 \times 10^{-11}$ & 0.748 \\
\hline $\mathrm{E}_{\mathrm{a}}(\mathrm{KJ} / \mathrm{mol})$. & 40.121 & 52.106 & 0.297 \\
\hline$\overline{\mathbf{R}^{2}}$ & 0.485 & 0.632 & 0.874 \\
\hline
\end{tabular}

The effect of temperature on the sticking probability was evaluated throughout the temperature range from 293 to $318 \mathrm{~K}$ by calculating the surface coverage at the various temperatures. Table 3 also indicated that the values of $S^{*} \leq 1$ for Amberjet $1500 \mathrm{H}$, Amberjet $1300 \mathrm{H}$ and Amberlite IRC86 resins, hence the sticking probability of the $\mathrm{Mn}$ (II) ion onto the three resin systems are very high.

The apparent activation energy $\left(E_{a}\right)$ and the sticking probability $\left(S^{*}\right)$ are estimated from the plot (Fig. not shown). The positive values of the apparent activation energy $\left(E_{a}\right)$ also indicated that the higher solution temperature favors the adsorption process and also the adsorption process is endothermic in nature[58].

\section{REFERENCES}

1. Ngah W.S.W., M.A.K.M Hanafiah; Bioresour. Technol., 99 (2008) 3935-3948.

2. Erdem, E., N. Karabiner, R. Denat; J. Colloid Interf. Sci., 280 (2004) 309-314.

3. Fonseca M.G., M.M. de Oliveira, L.N.H. Arakaki,; J. Hazard. Mater., 137 (2006) 288-292.

4. Henriksson J., H. Tjalve; Toxicol. Sci., 55 (2000) 392-398.

5. Suguna M., N.S. Kumar, M.V. Subbaiah, A. Krishnaiah; J. Chem. Pharm. Res., 2 (2010) 7-20.

6. Kose T.D., B.D. Gharde, S.B. Gholse; J. Chem. Pharm. Res., 4 (2012) 2021-2028.

7. Taffarel S.R., J. Rubio; Min. Eng., 22 (2009) 336-343.

8. Meena A.K., G.K. Mishra, P.K. Rai, C. Rajagopal, P.N. Nagar; J. Hazard. Mater., 122 (2005) 161-170.

9. Taffarel S.R., J. Rubio; Min. Eng., 23 (2010) 1131-1138.

10. Chakravarty R., D.C. Rupainwar; Environ. Technol, 20 (1999) 397-403.

11. Bosco S.M.D., R.S. Jimenez, C. Vignado, J. Fontana, B. Geraldo, F.C.A. Figueiredo, D. Mandelli, W.A. Carvalho; Adsorption, 12 (2006) 133-146.

12. Moreno-Pirajan J.C., V.S. Garcia-Cuello, L. Giraldo; Adsorption, 17 (2011) 505-514.

13. Jusoh A.B., W.H. Cheng, W.M. Low, A. Nora'aini, M.J.M.M. Noor,; Desalination, 182 (2005) 347-353.

14. Ghaedia M., B. Sadeghiana, A. Amiri Pebdania, R. Sahraeib, A. Daneshfarb, C. Duranc; Chem. Eng. J., 187 (2012) 133-141.

15. Rengaraj S., S.H. Moon; Water Res. 36 (2002) 1783-1793.

16. Ho Y.S., D.A. J. Wase, C.F. Forster, Water Res., 29 (1995) 1327-1332.

17. Ling P.P., F.Q. Liu, L.J. Li, X.S. Jing, B.R. Yin, K.B. Chen, A.M. Li; Talanta, 81 (2010) 424-432

18. Congcong S., C. Chen, T. Wen, Z. Zhao, X. Wang, A. Xu; J. Colloid and Interf. Sci., 456 (2015) 7-14.

19. Lichun F., C. Shuang, F. Liu, A. Li, Y. Li, Y. Zhou, H. Song; J. Hazard. Mater., 272 (2014) 102-111.

20. Asif A. K., S. Shaheen; Solid State Sciences. 16 (2013) 158-167.

21. Freundlich H.M.F.; J. Phys. Chem., 57 (1906) 385-470.

22. Balaz M., Z. B.akova, P. Balaz, A. Zorkovska, Z. Dankova, J. Brianc; J. Colloid and Interface Science, 454 (2015) $121-133$. 
23. Langmuir I.; J. Am. Chem. Soc., 40 (1918) 1361-403.

24. Yogeshwar N. T., A.K. Jana; J. Environm. Chem. Eng., 3 (2015) 1393-1398.

25. Giorgos M., D. Mitrogiannis, A. Celekli, H. Bozkurt, D.Georgakakis, C. V. Chrysikopoulos; Chem. Eng. J., 259 (2015) 806-813.

26. Tingshun J., W. Liu, Y. Mao, L. Zhang, J. Cheng, M. Gong, H. Zhao, L. Dai, S. Zhang, Q. Zhao; Chem. Eng. J., 259 (2015) 603-610.

27. Dubinin, M.M., L.V. Radushkevich;Chem. Zentr, 1 (1947) 875-890.

28. Rhulani N. N., G. S. Simate, S. Ndlovu; J. Environm. Chem. Eng., 3 (2015) 1258-1266.

29. Temkin I.M., V. Pyzhev; Acta Physiochem. SSR 12 (1940) 217-222.

30. Alicia E. C., J. C. Medina-Llamas, L. Maqueira, C. A.S. Andrade ,K.G.B. Alves, C. P. Melo; Chem. Eng. J., 281 (2015) 826-836.

31. Aleksandra B., P. Oleszczuk, R. Dobrowolski; Bioresource Technol, 196 (2015) 540-549.

32. Graeme J. M., S. J. Couperthwaite, M. Bruyn, C. W. Leung; Chem.Eng. J., 280 (2015) 525-535.

33. Burke, M.D.M., M. A. Morris, J.D. Holmes; Sep. and Purif. Technol, 104 (2013) 150-159.

34. Limei C., Y. Wang, L. Gao, L. Hu, L. Yan, Q. Wei, B. Du; Chem. Eng. J. 281 (2015) 1-10.

35. Tan X.L., C.L. Chen, S.M. Yu, X.K. Wang; Appl. Geochem., 23 (2008) 2767-2777.

36. Ozcan A., E.M. Oncu, A.S. Ozcan; Colloids Surf. A, 277 (2006) 90-97.

37. Mark D. G. L., E. D. Flores, M. Chela. B. C., M. Lu; Bioresource Technol., 192 (2015) 841-844.

38. Lagergren, S.; Handl., 24 (1898) 1-39.

39. Malihe F., M.Beheshti, H. Sabzyan; J. Molecular Liquids, 211 (2015) 1060-1073.

40. Ho Y.S., G. McKay; Chem. Eng. J., 70 (1998) 115-124.

41. Jingjing W., Z. Lia; J Hazard. Mater., 300 (2015) 18-28.

42. Weber W.J. and J.C. Morris; J. Sanit. Eng. Div. ASCE., 89 (1963) 31-59.

43. Xiaofei M., X. Liu, D. P. Anderson, P. R. Chang; Food Chem., 181 (2015) 133-139.

44. Chien S.H., W.R. Clayton; Soil Sci. Soc. Am. J., 44 (1980) 265-268.

45. Özacar M., and I.A. Sengil; Process Biochem., 40 (2005) 565-572.

46. Hyder A.H.M.G., S. A. Begum, N. O. Egiebor; J Environm.Chem. Eng., 3 (2015) 1329-1336.

47. Shek, T.H., Ma, A., V.K.C. Lee, G. McKay; Chem. Eng. J. 146(2009) 63-70.

48. Tan Y.S. Ho, G. McKay; Process Biochem., 38 (2003) 1047-1061.

49. Ping T., J. Sun, Y. Hu, Z. Fang, Q. Bi, Y. Chen, J. Cheng; J. Hazardous Mater., 297 (2015) 251-260.

50. Yu K., C. Gu, S.A. Boyd, C. Liu, C. Sun, B.J. Teppen, H. Li; Environ. Sci. Technol., 46 (2012) 8969-8975

51. Zhang, M.C. Q. Zhou, Y. Zhou, A.M. Li, C.D. Shuang; Chinese Chem. Lett., 23 (2012) 1267-1270.

52. Liu F.Q., L.J. Li, P.P. Ling, X.S. Jing, C.H. Li, A.M. Li, X.Z. You; Chem. Eng. J., 173 (2011) 106-114.

53. Mehmet U.; Microporous and Mesoporous Materials, 119 (2009) 276-283.

54. Michał C, G. Schroeder; Chem. Eng. J., 263 (2015) 402-411.

55. Qiong L., J.Yu, F. Zhou, X. Jiang; Colloids and Surfaces A: Physicochem. Eng. Aspects 482 (2015) 306-314.

56. Yanping Z., N. Gao, Q. Wang, X. We; Colloids and Surfaces A: Physicochem. Eng. Aspects, 468 (2015) $114-121$.

57. Sushanta D., A.Maity, K. Pillay; J. Environ. Chem. Engineering, 2 (2014) 260-272.

58. Singha B., S. K. Das; Colloids and Surf. B: Biointer., 107 (2013) 97- 106. 